\title{
Abundance and diversity of zooplankton in the Tigris River Northern of Basrah, Iraq
}

\begin{abstract}
Seasonally variations of the quality and quantity of zooplankton were studied in two stations in the terminal sector of Tigris River and one station at the confluence of the Tigris and Euphrates area, in Al-Qurnah North of Basrah City, during October 2015 to

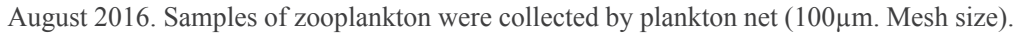
Salinity changed from $1 \%$ at St. 2 to $1.8 \%$ at St. 3, the $\mathrm{pH}$ varied from $7.5-8.2$ and the dissolved oxygen from $6 \mathrm{mg} / 1$ to $8.7 \mathrm{mg} / 1$ at St. 3 and St. 1 respectively. In study area the population density of zooplankton ranged between 20.3ind. $/ \mathrm{m}^{3}$ during Autumn and $243.41 \mathrm{ind} . / \mathrm{m}^{3}$ during Winter at station 1 (Al-Jewaber Bridge). The results showed that the Crustaceans were the dominated group that comprised $92.9 \%, 93.1 \%$ and $98.1 \%$ in study area respectively. Copepoda were the dominant in three stations, which constituted about $43.8 \%$ followed by Cladocera $35.2 \%$, Cirripede larvae $7.2 \%$, and Zoea of shrimp $4.2 \%$ of the total zooplankton respectively. Maximum richness (D) of (1.66) was obtained at station 1 during summer and autumn and higher Diversity $(\mathrm{H})$ of $(1.41)$ was recorded at station 1 during spring, while higher evenness $(J)$ of $(0.70)$ was obtained at station 2 during summer. The Jaccard's index values were close and revealed a higher similarity between stations 1 and 2 , and lower values between stations 1 and 3 .
\end{abstract}

Keywords: zooplankton, abundance, diversity Tigris River, North of Basrah
Volume 8 Issue 5 - 2019

\author{
Shaker G Ajeel, Mohammad F Abbas, \\ Dawood S Abdullah \\ Department of Marine Biology, University of Basrah, Iraq
}

Correspondence: Shaker G Ajeel, Department of Marine Biology, Marine Science Centre, University of Basrah, Iraq, Tel 077II799788,Email shaker_ajeel@yahoo.com

Received: September 13, 2019 | Published: October 25, 2019

\section{Introduction}

Zooplankton are important components of food webs in aquatic ecosystems throughout the world, channeling energy and nutrients from algae and bacteria to fish and other aquatic animals. Because they are highly productive and important in fish diets, an improved understanding of zooplankton production and growth can be applied to increase fish production in aquaculture facilities and in the aquatic environments. Therefore, the interest has been focused here on this important group, as it has not been well documented.

However, the research on the zooplankton of Basrah extends back to Gurney ${ }^{1}$ who for the first time surveyed freshwater Crustaceans of the lower Mesopotamia. In Basra the freshwater bodies include; Shatt Al-Arab River, Garmat-Ali River, Shatt Al-Basrah Canal and the marshes. The studies of zooplankton at Shatt Al-Arab River include; Salman et al. ${ }^{2}$ investigated the monthly changes of the zooplankton from 1982-1984, AL-Zubaidi and Salman ${ }^{3}$ and Ajeel et al ${ }^{4}$ study zooplankton in Central and Southern of Shatt Al-Arab. Moreover, Ajeel $^{5}$ and Ajeel $^{6}$ studyabundance and distribution of the zooplankton in Shatt Al-Arab, Shatt Al-Basrah and Khour Al-Zubair Channels. Later, Ajeel ${ }^{7}$ studied seasonal variations of zooplankton abundance in Shatt Al-Arab River. While, Ajeel et al. ${ }^{8}$ surveyed the zooplankton of Garmat-Ali River. At the Basrah Marshes Southern Iraq ALSaboonchi et al. ${ }^{9}$ studied the zooplankton(near Garmat-Ali River), qualitatively and quantitatively, between 1980 and 1981, Ajeel et al. ${ }^{10}$ studied the seasonal abundance of zooplankton in the southern Iraqi Marshes and Ajeel et al. ${ }^{11}$ studied seasonal variations of zooplankton in Al-Hammar Marsh.

However, the earliest studies were mainly concerned with the taxonomy of Cladocera and to a lesser extent of Copepoda, whereas the latter articles were investigating the abundance and distribution of Cladocera and Copepoda and only few papers were concerned with
Rotifera abundance. Therefore, there is no thorough investigation of the various groups of zooplankton throughout different stations in north Basrah and for one complete year. For this reason and for estimating the zooplankton production in various localities in Basrah, which has not been conducted before, the present study was carried out.

\section{Materials and methods}

\section{Study area}

The study was carried out between October 2015 and August 2016 on a seasonally basis. Samples were taken from three stations south Tigris River, North of Basrah (Figure 1). The first station near the Al-Jewaber Bridge $\left(31^{\circ} 0953^{\prime} 0.45^{\prime \prime} \mathrm{N}\right.$ and $47^{\circ} 2556^{\prime}$ 0.89"E), Second station near the Hamay on Bridge $\left(31^{\circ} 0748^{\prime} 0.15^{\prime \prime} \mathrm{N}\right.$ and $47^{\circ} 2638^{\prime}$ $0.79^{\prime \prime} \mathrm{E}$ ) and the third station Shatt Al-Arab in Al-Qurna region (near the confluence of the Euphrates and Tigris) $\left(31^{\circ} 0042^{\prime} 71^{\prime \prime} \mathrm{N}\right.$ and $47^{\circ} 2623^{\prime} 0.23^{\prime \prime} \mathrm{E}$ )

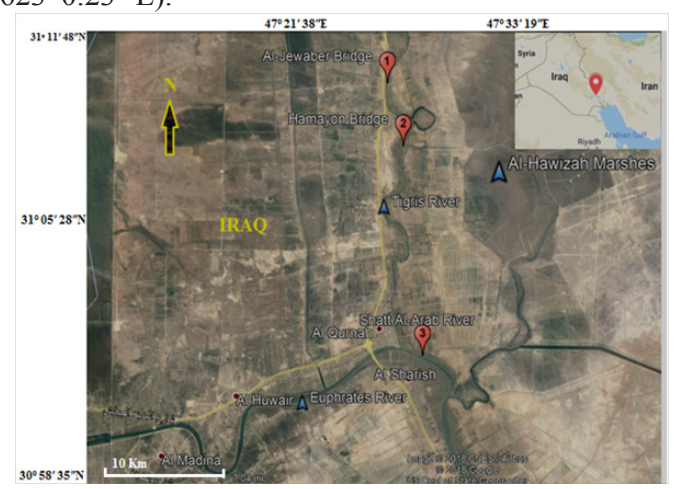

Figure I Map of the study area taken by using Google Earth program. 


\section{Sample collection}

Zooplankton samples were collected seasonally from surface water by using a $100 \mu \mathrm{m}$ mesh-sized zooplankton conical tow net and having a mouth aperture of $40 \mathrm{~cm}$ in diameter. A digital flow meter was mounted in the middle of the mouth of the zooplankton net. The net was horizontally towed behind a boat running at its lowest speed for 10-15 minutes, and then collect the zooplankton that have been retained by the net. The reading of the flow meter was taken before and after towing. At each station, samples of zooplankton were collected, transferred to containers (plastic bottles). The plankton samples were immediately fixed in $4 \%$ formaldehyde.

Water temperatures were measured by a thermometer with $0.1^{\circ} \mathrm{C}$ sensitivity. Salinity and $\mathrm{pH}$ measurements were performed by YSI 556MPS. Dissolved oxygen concentrations were measured by Winkler method. Turbidity were measured by HANNA instrument, Microprocessor Turbidity Meter HI 93703.

In the laboratory, samples were poured into a graduated vessel, and diluted if densely populated. Then a $10 \mathrm{ml}$ subsample was taken and placed in a Bogorov chamber, examined and counted under a dissecting microscope. This procedure was repeated for 3 times, and then the whole sample was examined for the rare species.

The volume of water was calculated using the method of De Bernardi. ${ }^{12}$

$$
V=\Pi r^{2} d
$$

Where: $\mathrm{V}=$ volume of water filtered by the net and is measured in cubic meters, $\Pi=(3.14)$, $r=$ half diameter of the net mouth aperture, $(20 \mathrm{~cm}), \mathrm{d}=$ number of revolutions of the flow meter multiplied at 0.3 .

Then the result was dividing by 10,000 to convert the result unit per cubic meter. The number of individuals were calculated in the sample diluted to $1000 \mathrm{ml}$ in the manner prescribed by $\mathrm{APHA}^{13}$ and expressed the result in cubic meter

$$
\text { No. } / m^{3}=(C X V I) /(\text { VII XVIII })
$$

Where: $\mathrm{C}=$ the number of individuals in the subsample

$\mathrm{VI}=$ volume of sample $(\mathrm{ml})$.

VII $=$ the size of the subsample $(10 \mathrm{ml})$.

$\mathrm{VIII}=$ volume of water filtered in cubic meters

\section{Ecological Indices}

\section{a. Diversity index (H) Shannon Weaver}

The diversity index $(\mathrm{H})$ was calculate from the equation of Shannon-Weaver ${ }^{14}$ as follows:

Where:

$$
H=-(n i / N) \ln (n i / N)
$$

$\mathrm{ni}=$ Number of members of the same species

$\mathrm{N}=$ The total number of individuals in the sample

\section{b. Evenness (J)}

Evenness $(\mathrm{J})$ was calculated by the equation of Pielou ${ }^{15}$

$$
J=H / \ln S
$$

Where:

$\mathrm{H}=$ Shannon Weaver diversity index

$\mathrm{S}=$ Number of species

c. Richness index (D)

Richness was calculated by the equation of Margalef ${ }^{16}$ as follows:

$D=S-1 / \ln N$

Where:

$\mathrm{D}=$ richness index

$\mathrm{S}=$ total number of species

$\mathrm{N}=$ total number of individuals

\section{d. Jaccard's similarity index Ss\%}

Jaccard's similarity index $\mathrm{Ss} \%$ was calculated according to Jaccard $^{17}$, as follows: -

$$
\text { Ss } \frac{a}{a+b+c}=\times 100
$$

Where:

a-The number of species of Cladocera found in A and B samples.

b-The number of species of Cladocera found in sample B and not found in sample A.

C-The number of species of Cladocera found in sample A and not found in sample B.

\section{Statistical analysis}

The correlation coefficient between zooplankton and environmental and physical factors was calculated using statistical program Canoco (2004).

\section{Results and discussion}

The zooplankton distribution varies both spatially and temporally according to the environmental conditions prevailing in the region. Differences may also arise due to the nature of distribution of the zooplankton, namely patchiness that may be the cause of the great variations in the catches of the nets. ${ }^{18}$ Moreover, the mesh-size of the net is an important factor controlling the quality and quantity of the catch.

\section{Hydrographic of the stations}

Water temperatures at three stations are very close to each other, it ranged between $9.5^{\circ} \mathrm{C}$ (in January 2016) at station 1 (Al-Jewaber Bridge) and $37.5^{\circ} \mathrm{C}$ (in Summer 2016) at station 3 (Shatt Al-Arab). Salinity changed from $1 \%$ at station 2 (Hamayon Bridge) to $1.8 \%$ at station 3. The $\mathrm{pH}$ varied from 7.5-8.2 and the dissolved oxygen from $6 \mathrm{mg} / 1$ to $8.7 \mathrm{mg} / 1$ at station 3 and station 1 respectively. While the highest value of turbidity 99.8 NTU were encountered during winter at station 1, whereas the lowest value $8.8 \mathrm{NTU}$ were recorded during spring at station 3. Chlorophyll-a values ranged from $0.58 \mathrm{mg} /$ $\mathrm{m}^{3}$ during winter at stations $2 \& 3$ to $8.6 \mathrm{mg} / \mathrm{m}^{3}$ during summer and spring at station 3, Table 1 . 
Table I Water temperatures, Salinity, $\mathrm{pH}$, dissolved oxygen, turbidity and Chlorophyll a at study stations during October $20 \mathrm{I} 5$ to August $20 \mathrm{I} 6$

\begin{tabular}{|c|c|c|c|c|c|c|c|}
\hline Seasons & Stations & $\begin{array}{l}\text { W.T. } \\
\left({ }^{\circ} \mathrm{C}\right)\end{array}$ & $\begin{array}{l}\text { Sal. } \\
\text { (\%०) }\end{array}$ & $\mathbf{P H}$ & $\begin{array}{l}\text { D.O. } \\
\text { (mg/l) }\end{array}$ & $\begin{array}{l}\text { Turbidity } \\
\text { (NTU) }\end{array}$ & Chlorophyll a \\
\hline \multirow{3}{*}{ Autumn } & St. I & 23 & 1.12 & 7.9 & 6.8 & 97.8 & 2.98 \\
\hline & St. 2 & 23 & 1.14 & 7.7 & 6.3 & 10.3 & 6.36 \\
\hline & St. 3 & 24 & 1.19 & 7.8 & 6.0 & 16.9 & 2.60 \\
\hline \multirow{3}{*}{ Winter } & St. I & 19.5 & 1.35 & 7.8 & 8.7 & 99.8 & 2.02 \\
\hline & St. 2 & 20 & 1.4 & 8.0 & 8.1 & 38.5 & 0.58 \\
\hline & St. 3 & 21 & I.4 & 7.7 & 7.6 & 27.7 & 0.58 \\
\hline \multirow{3}{*}{ Spring } & St. I & 24.5 & 1.07 & 8.2 & 8.0 & 35.3 & 2.89 \\
\hline & St. 2 & 24.8 & 1.0 & 8.0 & 7.9 & 47.3 & 2.89 \\
\hline & St. 3 & 25.8 & I.I & 7.8 & 7.6 & 8.83 & 8.6 \\
\hline \multirow{3}{*}{ Summer } & St. I & 37.4 & 1.4 & 7.8 & 6.6 & 56.8 & 2.89 \\
\hline & St. 2 & 37.3 & 1.5 & 7.6 & 6.4 & 59.5 & 2.89 \\
\hline & St. 3 & 37.5 & 1.8 & 7.5 & 6.1 & 9.9 & 8.6 \\
\hline
\end{tabular}

The present results indicate that the density of zooplankton was few in comparison with other areas in Basra. It was found some differences in the abundance of zooplankton among the three stations sampled. This is probably due to the environmental conditions. It is obvious that the highest density of zooplankton recorded during the Winter 2016 as the peak density $\left(243.4 \mathrm{ind} / \mathrm{m}^{3}\right)$ was reported in station 1 (Al-Jewaber Bridge), while the low density $20.3 \mathrm{ind} / \mathrm{m}^{3}$ was reported in Autumn at the same station. Moreover Abbas et al. ${ }^{19}$ studied the abundance and distribution of Zooplankton in the northern sector of Shatt Al-Arab, they reported the zooplankton density it was ranged between (79-65170ind $/ \mathrm{m}^{3}$ ), where Cirripede larvae dominated the zooplankton community at all the stations. Cladocera was second important group, followed by Copepoda. However, Salman et al. ${ }^{2}$ reported a density of zooplankton in Shatt Al-Arab, ranged between 21-642ind/ $\mathrm{m}^{3}$ during May-December and January 1982/83 at Mhajran near the Basrah city center. This controversy is, perhaps, largely due to the difference in mesh-size of the net used, as the net used by the latter authors was $200 \mu \mathrm{m}$. However, further downstream, at Al-Seba the density of zooplankton varied from $97-13438 \mathrm{Ind} / \mathrm{m}^{3}$, and two peaks of zooplankton abundance were found, one during summer and the other at the end of winter. ${ }^{3}$

The results showed the high densities of zooplankton were recorded during the winter at station 1 and 2 while at station 3 the high density were recorded during summer, and less density recorded during the autumn in three stations, and there is no effect of environmental factors on the density of the zooplankton. The differences of average density of zooplankton between three stations were few $\left(110.8 \mathrm{ind} / \mathrm{m}^{3}\right)$, $\left(74.3 \mathrm{ind} / \mathrm{m}^{3}\right)$ and $\left(96.4 \mathrm{ind} / \mathrm{m}^{3}\right)$ respectively. The reason may be due to the nature of distribution of the zooplankton, namely patchiness that may be the cause of the great variations in the catches of the nets. ${ }^{18}$

\section{Study areas}

In the study areas the seasonal variation of average density of zooplankton ranged between $51.3 \mathrm{ind} / \mathrm{m}^{3}$ in Autumn to $148.1 \mathrm{ind} /$ $\mathrm{m}^{3}$ in Winter, Figure 2 . While in study stations the average density of zooplankton ranged between $73.3 \mathrm{ind} / \mathrm{m}^{3}$ at station 2 (Hamayon Bridge) to $142.4 \mathrm{ind} / \mathrm{m}^{3}$ at station 3 (Shatt Al-Arab) Table 2. The average density in all stations was $118.7 \mathrm{ind} / \mathrm{m}^{3}$. The Crustaceans was dominant in this area $(95 \%)$, Copepods constitute $43.7 \%$, the second important group was Cladocerans 35.3\%, Cirripede larvae 7.2\% Zoea of shrimp 4.1\%, Amphipods 2.5\% then Bivalve larvae $2.4 \%$ of the total zooplankton Figure 3. Cyclopoida of Copepoda exhibited the highest peak is reached $59.2 \mathrm{ind} / \mathrm{m}^{3}$ in station 3 , which comprised $39.9 \%$ of total zooplankton.

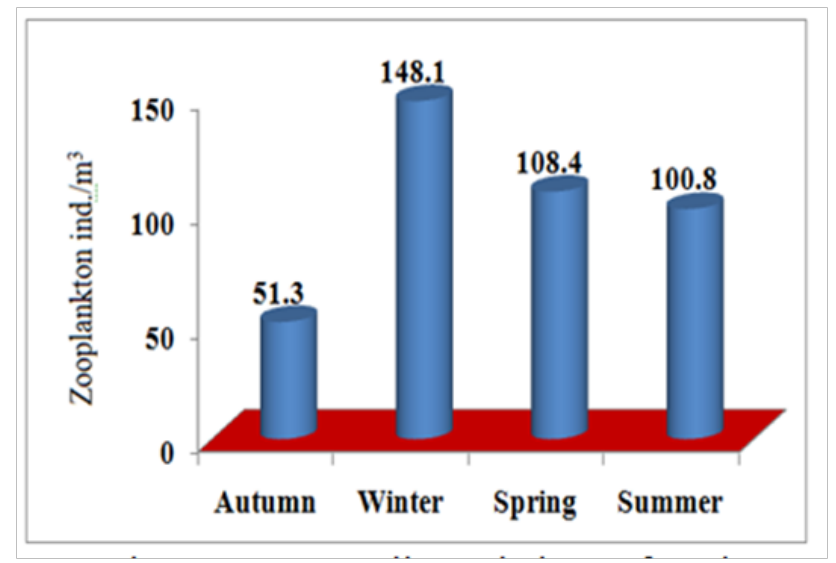

Figure 2 Seasonally variations of total zooplankton density (ind $/ \mathrm{m}^{3}$ ) at three stations. 


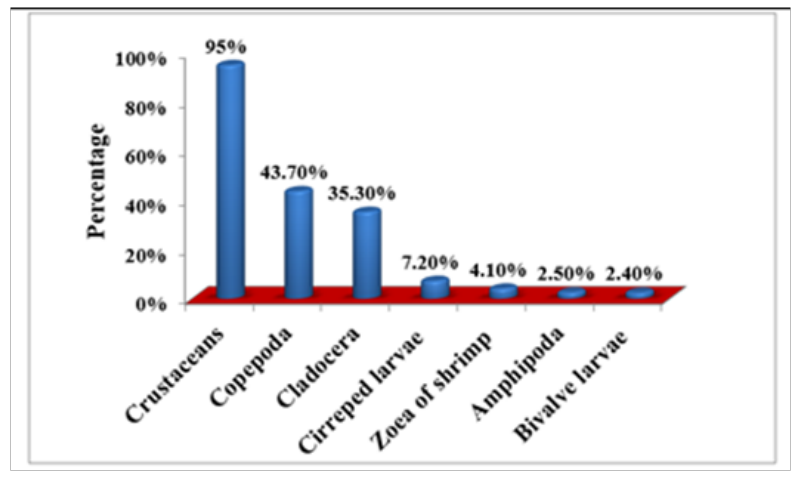

Figure 3 Percentages of important groups of zooplankton in three stations.

Table 2 The average density of Zooplankton (ind. $/ \mathrm{m}^{3}$ ) at Study area

\begin{tabular}{|c|c|c|c|}
\hline Zooplankton & St. I & St. 2 & St. 3 \\
\hline Calanoida & 4.05 & I.I & 0.2 \\
\hline Cyclopoida & 49.4 & 33.4 & 59.2 \\
\hline Harpacticoida & 0.7 & 1.1 & 3.2 \\
\hline Nauplii larvae & 1.6 & 0.5 & 1.2 \\
\hline Total Copepoda & 55.9 & 36.1 & 64 \\
\hline Cladocera & 54.1 & 24.4 & 47 \\
\hline Insect larva & 0.2 & 0.6 & 2.3 \\
\hline Amphipoda & 7 & 1.9 & 0.2 \\
\hline Isopoda & - & - & 0.01 \\
\hline Ostracoda & 0.03 & 3 & 0.3 \\
\hline Cirripede larvae & 0.5 & - & 25.2 \\
\hline Zoea of shrimp & 12.1 & 2.2 & 0.4 \\
\hline Zoea of crab & 0.7 & - & 0.3 \\
\hline Total Crustaceans & 130.6 & 68.3 & 139.8 \\
\hline Rotifera & 0.3 & 4.4 & 2.2 \\
\hline Polychaete larvae & 1.2 & 0.6 & 0.3 \\
\hline Fish larvae & - & 0.005 & 0.02 \\
\hline Bivalve larvae & 8.5 & - & - \\
\hline Gastropoda & 0.007 & 0.007 & - \\
\hline Total Zooplankton & 140.6 & 73.3 & 142.4 \\
\hline
\end{tabular}

\section{a. Station 1 (Al-Jewaber Bridge)}

The population density of zooplankton ranged between 20.3ind/ $\mathrm{m}^{3}$ in Autumn 2015 to $243.4 \mathrm{ind} / \mathrm{m} 3$ in Winter 2016 Table 3. The average density was $140.6 \mathrm{ind} / \mathrm{m}^{3}$. The Crustaceans was dominant in this area $(92.9 \%)$, where their numbers ranged between $18.8 \mathrm{ind} / \mathrm{m}^{3}$ in Autumn to $242.2 \mathrm{ind} / \mathrm{m}^{3}$ during Winter. Total Copepoda constitute $39.7 \%$. The second important group was Cladocera $38.4 \%$, Zoea of shrimp $8.6 \%$ then Bivalve larvae $6 \%$ of the total zooplankton Figure 4. Cyclopoida of Copepoda exhibited the highest peak is reached in Summer $\left(134 \mathrm{ind} / \mathrm{m}^{3}\right)$, which comprised $35.1 \%$ of total zooplankton and $88.3 \%$ of total Copepoda, while Cladocera exhibited a rise in Winter $2016\left(211 \mathrm{ind} / \mathrm{m}^{3}\right)$.
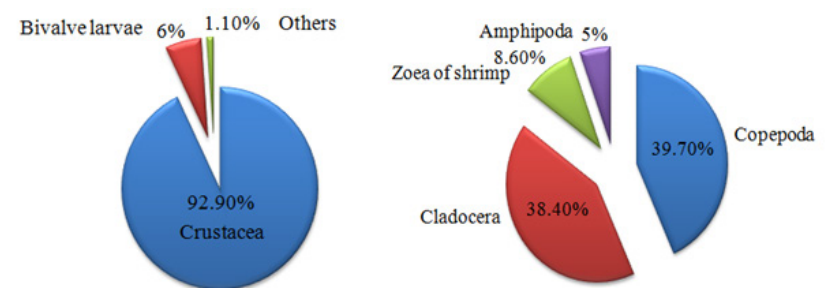

Figure 4 Percentage of important groups of zooplankton in St. I Al-Jewaber Bridge.

Table 3 Seasonal Zooplankton density (ind. $/ \mathrm{m}^{3}$ ) at Station I Al-Jewaber Bridge

\begin{tabular}{|c|c|c|c|c|}
\hline Zooplankton & Autumn & Winter & Spring & Summer \\
\hline Calanoida & 0.6 & 8.1 & 1.8 & 5.7 \\
\hline Cyclopoida & 10.5 & 21 & 32 & 134 \\
\hline Harpacticoida & 1 & 0 & 0 & 2 \\
\hline Nauplii larvae & 5 & 0 & 1.2 & 0.6 \\
\hline Total Copepoda & 17.1 & 29.1 & 35 & 142.3 \\
\hline Cladocera & 1.3 & 211 & 3 & 1 \\
\hline Insect larva & 0.3 & 0.1 & 0.6 & 0.01 \\
\hline Amphipoda & 0 & 0 & 18 & 10 \\
\hline Ostracoda & 0.1 & 0 & 0.01 & 0.01 \\
\hline Cirripede larvae & 0 & 2 & 0 & 0 \\
\hline Zoea of shrimp & 0 & 0 & 14.2 & 34.3 \\
\hline Zoea of crab & 0 & 0 & 2 & 1 \\
\hline Total Crustacea & 18.8 & 242.2 & $72.8 I$ & 188.62 \\
\hline Rotifera & 1.2 & 0.01 & 0 & 0 \\
\hline Polychaete larvae & 0.3 & 1.2 & 3.1 & 0.03 \\
\hline Bivalve larvae & 0 & 0 & 0 & 34 \\
\hline Gastropoda & 0 & 0 & 0 & 0.03 \\
\hline $\begin{array}{l}\text { Total } \\
\text { Zooplankton }\end{array}$ & 20.3 & $243.4 I$ & 75.91 & 222.68 \\
\hline
\end{tabular}




\section{b. Station 2 (Hamayon Bridge)}

The density of zooplankton ranged from $62.5 \mathrm{ind} / \mathrm{m}^{3}$ in Autumn 2015 to $90.15 \mathrm{ind} / \mathrm{m}^{3}$ in Winter 2016 Table 4 . The average density was $73.3 \mathrm{ind} / \mathrm{m}^{3}$. Crustaceans was the dominant groups constitute $93.1 \%$ of the total zooplankton and ranged between $50.6 \mathrm{ind} / \mathrm{m}^{3}$ in Summer to 88.4 ind./m3 in Winter. Total Cladocerans comprised $50.1 \%$ then Copepods $49.2 \%$, Rotifera $6.1 \%$ and Ostracods $4.0 \%$ of total zooplankton Figure 5. Cyclopoids was dominant of Copepoda that comprised $45.5 \%$ of total zooplankton and $92.6 \%$ of total Copepoda.

Table 4 Seasonal Zooplankton density (ind. $/ \mathrm{m}^{3}$ ) at Station 2 Hamayon Bridge

\begin{tabular}{|c|c|c|c|c|}
\hline Zooplankton & Autumn & Winter & Spring & Summer \\
\hline Calanoida & 0 & I & 1.4 & 1.9 \\
\hline Cyclopoida & 38.2 & 12.5 & 53 & 30 \\
\hline Harpacticoida & 2 & I & 1 & 0.3 \\
\hline Nauplii larvae & 0 & 0.7 & 1.4 & 0 \\
\hline Total Copepoda & 40.2 & 15.2 & 57.1 & 32.2 \\
\hline Cladocera & 12.2 & 72.5 & 10.02 & 3.02 \\
\hline Insect larva & 0.1 & 0.7 & 0.8 & I \\
\hline Amphipoda & 2 & 0 & 5 & 0.5 \\
\hline Ostracoda & 0 & 0 & I & 10.9 \\
\hline Zoea of shrimp & 5 & 0 & I & 3 \\
\hline Total Crustacea & 59.5 & 88.4 & 74.9 & 50.6 \\
\hline Rotifera & 2 & I & 2.8 & 12 \\
\hline Fish larvae & 0 & 0.02 & 0 & 0 \\
\hline Polychaete larvae & I & 0.7 & 0.8 & 0 \\
\hline Gastropoda & 0 & 0.03 & 0 & 0 \\
\hline $\begin{array}{l}\text { Total } \\
\text { Zooplankton }\end{array}$ & 62.5 & 90.15 & 78.5 & 62.6 \\
\hline
\end{tabular}

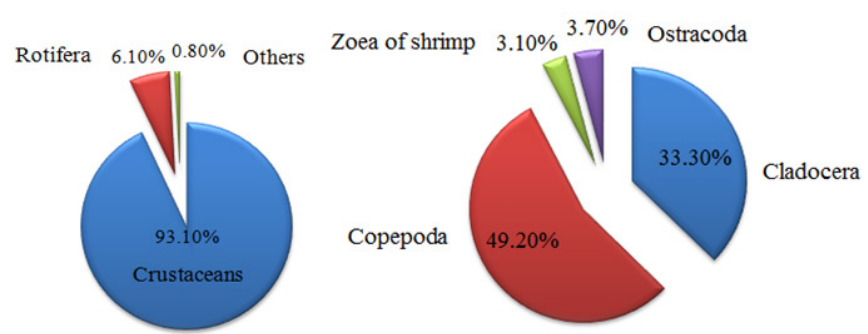

Figure 5 Percentage of important groups of zooplankton in St. 2 Hamayon Bridge.

\section{c. Station 3 (Shatt Al-Arab)}

Station three representing of the Euphrates and TigrisConfluence. The density of zooplankton ranged from 71 ind./m3 in Autumn 2015 to $217.1 \mathrm{ind} / \mathrm{m}^{3}$ in Summer 2016 Table 5 . The average density was $142.4 \mathrm{ind} / \mathrm{m}^{3}$. The Crustaceans was the dominant groups constitute $98.1 \%$ of the total zooplankton. Total Copepods comprised $44.9 \%$ then Cladocerans $33.0 \%$, Cirripede larvae $17.7 \%$ and Insect larvae
$1.6 \%$ of the total zooplankton Figure 6. Cyclopoids was dominant which comprised $41.6 \%$ of total zooplankton and $92.6 \%$ of total Copepoda.

Table 5 Seasonal Zooplankton density (ind. $/ \mathrm{m}^{3}$ ) at St. 3 (Shatt Al-Arab)

\begin{tabular}{|c|c|c|c|c|}
\hline Zooplankton & Autumn & Winter & Spring & Summer \\
\hline Calanoida & 0 & 0 & 0 & 1 \\
\hline Cyclopoida & 17 & II & 29 & 180 \\
\hline Harpacticoida & I & 4 & 3 & 5 \\
\hline Nauplii larvae & I & 2 & I & I \\
\hline $\begin{array}{l}\text { Total } \\
\text { Copepoda }\end{array}$ & 19 & 17 & 33 & 187 \\
\hline Cladocera & 44 & 88 & 30 & 26 \\
\hline Insect larvae & 3 & 2 & 4 & 0.1 \\
\hline Amphipoda & 0 & 0 & 0 & I \\
\hline Isopoda & 0 & 0 & 0.04 & 0 \\
\hline Ostracoda & 0 & 0 & 0.2 & I \\
\hline $\begin{array}{l}\text { Cirripedia } \\
\text { larvae }\end{array}$ & 1 & 0 & 100 & 0 \\
\hline Zoea of shrimp & 0 & 0 & I & 0.8 \\
\hline Zoea of crab & I & 0 & 0 & 0.1 \\
\hline $\begin{array}{l}\text { Total } \\
\text { Crustacea }\end{array}$ & 68 & 107 & 168.2 & 216 \\
\hline Rotifera & 3 & 3 & 2 & I \\
\hline $\begin{array}{l}\text { Polychaete } \\
\text { larvae }\end{array}$ & 0 & 0.8 & 0.6 & 0 \\
\hline Fish larvae & 0 & 0 & 0 & 0.1 \\
\hline $\begin{array}{l}\text { Total } \\
\text { Zooplankton }\end{array}$ & 71 & I 10.8 & 170.8 & 217.1 \\
\hline
\end{tabular}

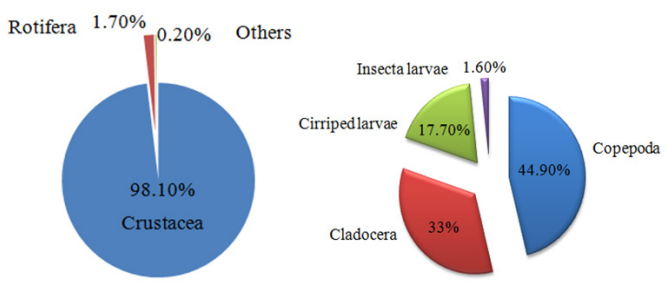

Figure 6 Percentage of important groups of zooplankton in Station 3 (Shatt Al-Arab).

These results are compared with those reported by other authors in various parts of inland waters of Iraq, Mangalo and $\mathrm{Akbar}^{20}$ found that the density of zooplankton in Diyala River, further to the north of Basrah, was $861 \mathrm{ind} / \mathrm{m}^{3}$ in February 1984 and only $0.4 \mathrm{ind} / \mathrm{m}^{3}$ during November 1984. Whereas Mangalo and $\mathrm{Akbar}^{21}$, reported density of zooplankton $3843 \mathrm{ind} / \mathrm{m}^{3}$ in January 1986 and $0.5 \mathrm{ind} / \mathrm{m}^{3}$ in October 1985 in Diyala River and 3-172ind/m $\mathrm{m}^{3}$ in July 1986 and March 1986, respectively in the Tigris River at Baghdad. Ajeel et al. ${ }^{4}$ reported the zooplankton density at St. 1 (Shatt Al-Arab at Al-Hartha north Basrah city) ranged between $110 \mathrm{ind} / \mathrm{m}^{3}$ in August 1996 to $1610 \mathrm{ind} / \mathrm{m}^{3}$ in 
April 1997. While at St. 6 Shatt Al-Arab (near the city center at AlAshar) ranged between $125 \mathrm{ind} / \mathrm{m}^{3}$ in January 1997 to $204 \mathrm{ind} / \mathrm{m}^{3}$ in April 1997.

\section{Ecological indices}

\section{a. Richness (D)}

Seasonal changes varied in richness values in the study stations which recorded as the highest rate (1.66) during the summer and autumn, and lower rate (0.91) during winter and the average value was (1.46) at first station, and the highest rate (1.60) during spring and lower rate (1.33) during the winter and the average value was (1.46) at second station, while the highest rate was 1.56 during the spring and lower rate (0.85) during the winter and the average value was (1.27) in the third station Figure 7.

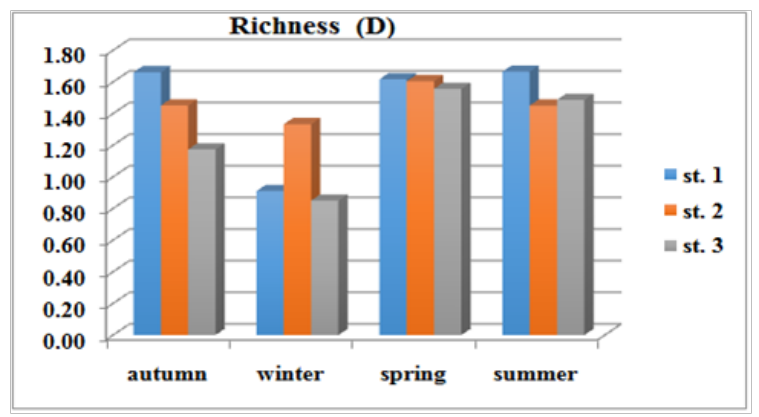

Figure 7 Seasonally changes of Richness (D) at three stations during October 2015 to August 2016.

\section{b. Diversity index (H) shannon weaver}

Varied diversity index values in the study stations was the highest value(1.41) during the spring and the lowest value (0.45) during the winter and the average value was (0.89) in the first station, while in the second station the highest value (1.61) recorded during the winter and the lowest value (0.99) during the spring and the average value was (1.01).Moreover, in the third station the highest value of diversity index was (1.14) during the spring and the lowest value (0.49) during the summer and the average value was $(0.83)$ Figure 8.

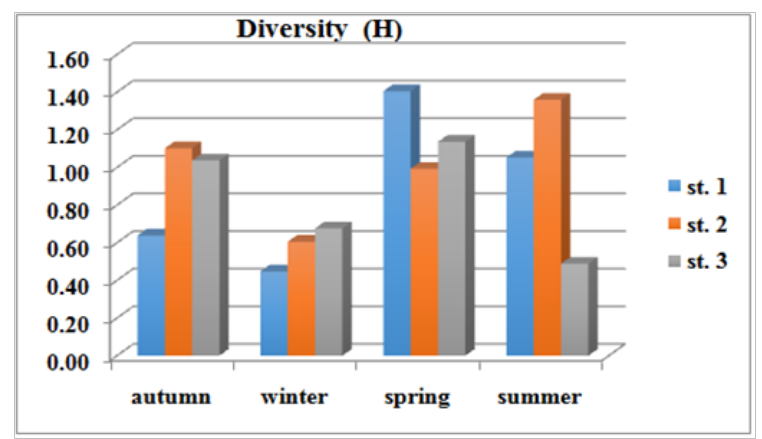

Figure 8 Seasonally variations of Diversity $(H)$ at three stations during October 2015 to August 2016.

\section{c. Evenness index (J)}

Figure 9 shows the annual average of Evenness index values, which recorded in the study stations. Evenness coefficient for the zooplankton reached highest value (0.68) during the spring and the lowest value (0.25) during the winter and the average value was $(0.43)$ in the first station. Whereas in the second station the highest value
(0.70) during summer and the lowest value (0.31) during winter and the average (0.51). While the highest value (0.58) during autumn and the lowest value $(0.22)$ during summer and the average $(0.43)$ in the third station.

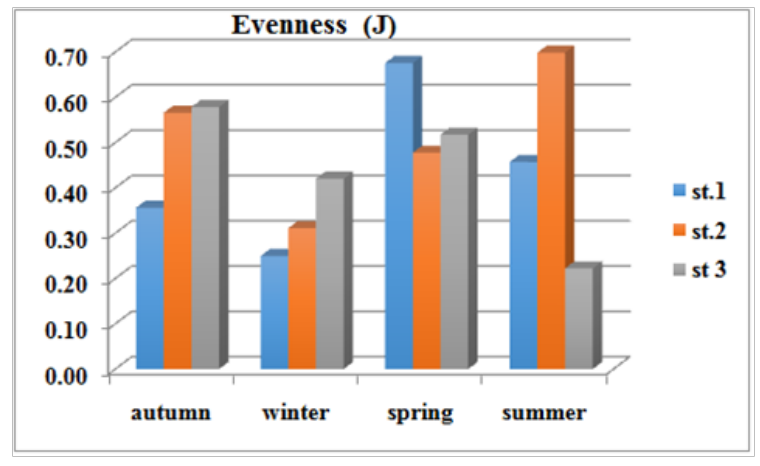

Figure 9 Seasonally changes of Evenness ( () at three stations during October 2015 to August 2016.

\section{d. Jacquard's Index}

Jaccard's similarity index was calculated for the zooplankton at three different stations; the highest similarity value was between stations (1) and (2) while the lowest value of the similarity between stations (1) and (3) Figure 10.

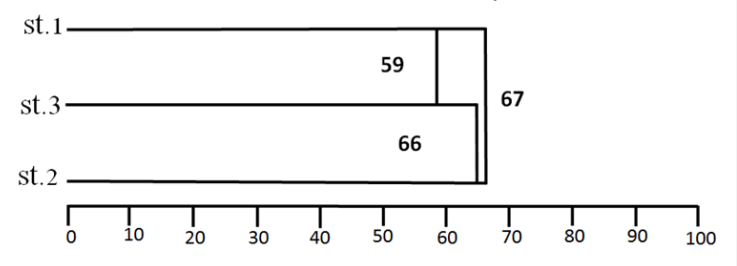

Figure 10 Cluster of the Similarity index (Jaccards) values of Group Zooplankton at three stations between October 2015 to August 2016 on a seasonally basis.

The results of the environmental evidence (Richness index (D), diversity index $(\mathrm{H})$, Shannon Weaver and Evenness index $(\mathrm{J})$ show low rate this evidence in the study stations has been attributed to pollution and environmental changes in this region and this is consistent with Al-Jizany ${ }^{22}$ and Ajeel and $\mathrm{Abbas}^{23}$ which reported the pollution due to reduce diversity index.

Correlation coefficient of environmental factors with zooplankton:

The correlation coefficients between the many physical and chemical properties included in the current study were calculated with the distribution of zooplankton. The results were as in Figure 11 shows the correlation between zooplankton and environmental factors, in the form, the Insect larvae group appears to correlate with chlorophyll-a significant and affected by other factors with little effect such as dissolved oxygen and temperatures. The effect of other physical factors is destitute. Gastropoda also affected by salinity, while the effect of Turbidity, water temperature and $\mathrm{pH}$ has little effect and chlorophyll-a and dissolved oxygen have no effect on this group. Significant positive relationships were found between Amphipoda, Rotifera, Copepoda, Fish larvae, Zoea of crab, Ostracoda, Zoea of shrimp and water temperature, whilethe effect of other environmental factors has had a weak. 
Table 6 shows a comparison of the density of zooplankton, Copepods, Cladocera and Cirripede larvae $\left(\mathrm{ind} / \mathrm{m}^{3}\right)$ in the current study compared with the previous studies in different regions and different stations at Marshes and Shatt Al-Arab.

Table 6 Density of zooplankton, Copepods, Cladocera and Cirripede larvae (ind./ $\mathrm{m}^{3}$ ) in different stations at Shatt Al-Arab River and Marshes

\begin{tabular}{|c|c|c|c|c|c|c|c|}
\hline \multicolumn{5}{|c|}{ Mish size } & \multicolumn{3}{|c|}{ Cirripede } \\
\hline & Study Area & $(\mathrm{mm})$ & Zooplankton & Copepods & Cladocera & larvae & References \\
\hline I & Shatt Al-Arab & 0.09 & II $10-2047$ & $30-1322$ & $0.3-229$ & $0-187$ & 4 \\
\hline 2 & Shatt Al-Arab & 0.09 & $70-27670$ & $6 I-20067$ & $4-10854$ & $0-1802$ & 24 \\
\hline 3 & Shatt Al-Arab & 0.12 & $667 \mid-28064$ & $4419-2582 \mid$ & $0-24$ & $269-1075$ & 25 \\
\hline 4 & Al-Huwaiza Marsh & 0.12 & $61-3309$ & $38-3155$ & $0.4-72$ & $0-30$ & 10 \\
\hline 5 & Al-Huwaiza Marsh & 0.12 & $21-9817$ & $7-1727$ & Sep-39 & $0-261$ & 26 \\
\hline 6 & Al-Izze river & 0.12 & $188-27 \mid 4$ & $168-2659$ & $10-290$ & $0-5$ & 10 \\
\hline 7 & Basrah Marshes & 0.12 & $52-2115$ & $8-1191$ & $0.4-235$ & $1.2-1287$ & 10 \\
\hline 8 & Al- Hammar Marsh & 0.12 & $197-8673$ & $4|-| 36 \mid$ & $61-6354$ & $0-2697$ & 26 \\
\hline 9 & Al- Hammar Marsh & 0.09 & $717-1209879$ & $79-40204$ & $111-1095$ & $79-1185628$ & 11 \\
\hline 10 & Central Marsh & 0.12 & 99 - 42655 & $48-20450$ & Jan-83 & $0-47$ & 26 \\
\hline II & Tigris River & 0.1 & $20-243$ & $15-142$ & $|-2| I$ & $0-2$ & Present study \\
\hline 12 & Shatt Al-Arab River & 0.1 & $71-217$ & $17-187$ & $26-88$ & $0-100$ & Present study \\
\hline
\end{tabular}

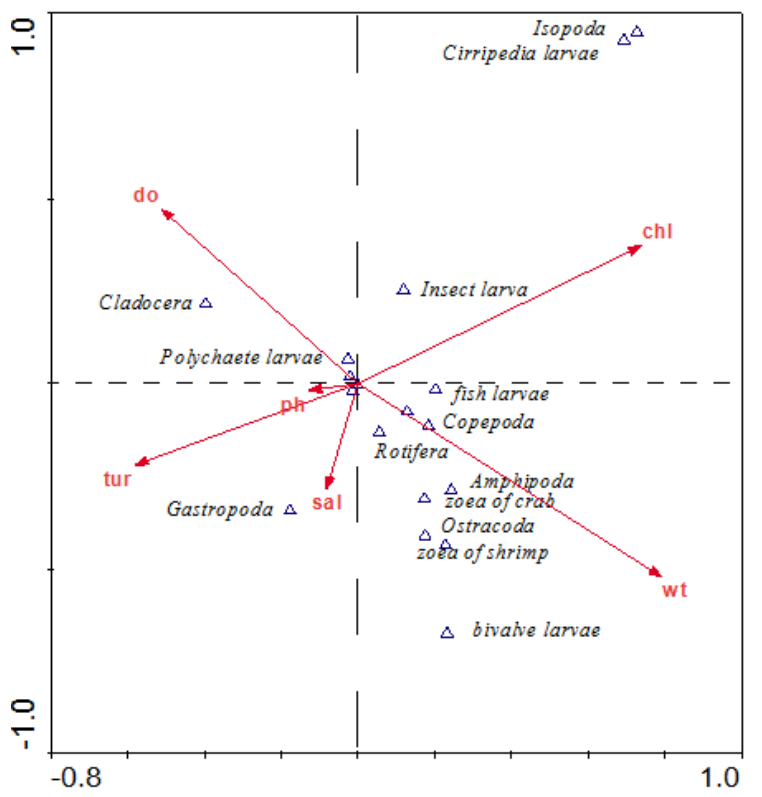

Figure I I CCA analysis of the correlation coefficients between zooplankton and the environmental factors during the study period.

\section{Acknowledgements}

None.

\section{Funding}

None.

\section{Conflicts of interest}

The author declares that there are no conflicts of interest.

\section{References}

1. Gurney R. Freshwater Crustacea collected by Dr. P. A. Buxton in Mesopotamia and (Persia). J Bombay natural History Society. 1921:27(4):835-844.

2. Salman SD, Marina BA. Ali MH, et al. Zoolpankton studies. In: Final report: The 18-month marine pollution monitoring and research programme in Iraq. Marine Science Center of Basrah University, Basrah-Iraq.1986; p.136-166

3. AL-Zubaidi AMH, Salman SD. Distribution and abundance of zooplankton in the Shatt AL-Arab estuary, North West Arabian Gulf, .Mesopot. J Mar Sci. 2001;16(2):187-199.

4. Ajeel SG, Salman SD, Ali MH. Zooplankton of Basrah district, Southern Iraq. Marsh bulletin. 2008;3(2):171-191.

5. Ajeel SG. Abundance and distribution of zooplankton in some waters in southern region of Iraq. Mesopot. J Mar Sci. 2004;19(1):95-115.

6. Ajeel SG. Distribution and abundance of zooplankton in Shatt AlBasrah and Khour Al-Zubair Channels, Basrah, IRAQ. Journal of Basrah Researches/Sciences. 2012;38(4):10-28.

7. Ajeel SG. Seasonal variations of zooplankton abundance in Shatt AlArab River, Southern Iraq. International Journal of Marine Science. 2016;6(58):1-8.

8. Ajeel SG, Abdulla SB, Mohammad HH. Abundance and distribution of the zooplankton in the Garmat-Ali River. Basrah $J$ of Agricultural Science. 2004;17(1):167-178.

9. AL-Saboonchi AA, Barak NA, Mohamed AM. Zooplankton of Garma marshes. Iraq J Biol Sci Rrs. 1986;17(1):33-40. 
10. Ajeel SG, Khalaf TA, Mohammad HH, et al. Distribution of zooplankton in the Al-Hawizah, Al-Hammar marshes and Al-Izzeriver south of Iraq. Marsh Bulletin. 2006;1(2):140-153.

11. Ajeel SG, Douabul AAZ, Abbas MF. Seasonal Variations of Zooplankton in Al-Hammar Marsh-Southern Iraq. Journal of Ecosystem \& Ecography. 2015;5(3):1-7.

12. De Bernardi R. Methods for the estimation of Zooplankton abundance. In: A manual on methods for the assessment of secondary Productivity in Fresh Waters. Downing JA, RigIer FH, editors. BP Hand book No. 17 Blakwell, Oxford.1984;55-86.

13. Andrew D Eaton. Standard methods for the examination of water and wastewater. 21st ed. American Public Health Association. Washington Dc. 2006.

14. Shannon CE, Weaver W. The mathematical theory of communication, Univ. Illinois press. 1964; p. 1-134.

15. Pielou EC. Shannon's formula as measure of specific diversity: Its use and misuse. Am Nat. 1966;100:463-465.

16. Margalef R. Perspectives in ecology theory. Univ. Chicago press, Chicago. 1968;111 p.

17. Jaccard P. Nouvelles researches sur la distribution florale. Bull Soc Vand Sic Nat. 1908;44: 223-270.

18. Raymont JEG. Plankton and productivity in the Ocean. 2nd ed. Zooplankton Pergamon Press. 1980; 824 p.
19. Abbas MF, Salman SD, Al-Mayahy SH. Diversity and seasonal changes of zooplankton communities in the Shatt Al-Arab River, Basrah, Iraq, with a special reference to Cladocera. Mesopot. J Mar Sci. 2014;29 (1): $51-70$.

20. Mangalo $\mathrm{HH}, \mathrm{Akbar}$ MM. Seasonal variation in population density of zooplankton in the lower reaches of Diyala River, Baghdad-Iraq. J Biol Scien Res. 1986;17(3):99-114.

21. Mangalo HH, Akbar MM. Comparative study of two populations of cladocerans in the Tigris and Diyala Rivers at Baghdad. J Biol Sci Res. 1988;19(1):117-128.

22. Al-Jizany HRI. Organic pollution and its effect on the diversity and abundance of plankton in the Shatt Al-Arab, Ashar and Rubat canals. M Sc. Thesis. Coll Edu Uni Basrah. 2005; p. 82

23. Ajeel SG, Abbas MF. Seasonal variations of the Cladocerans in the Shatt Al-Arab River, Southern Iraq. Iraqi J Aquaculture.2016;13 (1):66-85.

24. Al-Zubaidi AMH. Distribution and abundance of the zooplankton in the Shatt Al-Arab estuary and North-West Arabian Gulf PhD. Thesis, Basrah University. 1998; p.125.

25. Morad MSS. Zooplankton in Iraqi Marine Coastal and Estuarine Brackish Water and their Role as Hosts of Some Parasites. M.Sc. Thesis college of Education. University of Basra. 2011; p.116.

26. Salman SD, Abbas MF, Ghazi AH, et al. Seasonal changes in zooplankton communities in the re-flooded Mesopotamian wetlands, Iraq. Journal of Freshwater Ecology. 2014;29(3)1-16. 